\title{
Leuconostoc oenos sp.nov.
}

\author{
By ELLEN I. GAR VIE \\ National Institute for Research in Dairying, Shinfield, Reading
}

(Accepted for publication 24 March I967)

\begin{abstract}
SUMMAR Y
Nineteen strains of Gram-positive cocci isolated from wine and belonging to the genus Leuconostoc were examined and are considered to form a new species which is named Leuconostoc oenos. These strains differ from other leuconostocs because they grow better in a medium containing tomato juice than in yeast glucose citrate broth normally used in this laboratory for the genus. Furthermore, they grow well in media in which the $\mathrm{pH}$ value is too acid for other Leuconostoc species to initiate growth. The cultures of L. oenos do not form dextran from sucrose. They form acid from fructose, glucose, trehalose and aesculin, generally from melibiose and salicin. They may form acid from arabinose, xylose, galactose, mannose and cellobiose, but not from lactose, maltose, sucrose, raffinose, dextrin, glycerol, mannitol or sorbitol.
\end{abstract}

\section{INTRODUCTION}

Gram-positive cocci belonging to the genus Leuconostoc occur in wine as part of the normal bacteriological flora (Bidan, I956; Radler, I958; Ingraham, Vaughn \& Cooke, I960; Peynaud \& Domercq, I96I), but none of these reports satisfactorily identifies the Leuconostoc species which they described. Cultures obtained from Drs Radler, Peynaud and Ingraham were therefore examined and compared with strains of other species of the genus Leuconostoc held in the National Collection of Dairy Organisms (Shinfield) and described by Garvie (1960).

\section{METHODS}

Cultures. The strains of wine leuconostocs examined are listed in Table I. They were found to require conditions of growth different from those required by other species of the same genus. The media and methods used had therefore to be modified to suit the wine strains.

General media for, and cultivation of, wine leuconostocs. The cultures were grown in acidic tomato broth (ATB) consisting of (w/v): Evans peptone, $\mathrm{I} \cdot 0 \%$; Yeastrel, $0.5 \%$; glucose, $\mathrm{I} \cdot 0 \%$; $\mathrm{MgSO}_{4} .7 \mathrm{H}_{2} \mathrm{O}, 0.02 \% ; \mathrm{MnSO}_{4} .4 \mathrm{H}_{2} \mathrm{O}, 0.005 \%$; and $(\mathrm{v} / \mathrm{v})$ : tomato juice, $25 \%$; $\mathrm{pH}_{4} .8$; autoclaved at $121^{\circ}$ for $\mathrm{I} 5 \mathrm{~min}$.; before inoculation $0.5 \mathrm{ml}$. of $1.0 \%(\mathrm{~W} / \mathrm{v})$ solution of cysteine hydrochloride sterilized by filtration was added to each Io ml. of media. The cultures were incubated at $22^{\circ}$ for 3-4 days.

Stock cultures. Agar stabs were prepared by adding I.5\% agar to ATB. After inoculation these were incubated in anaerobic jars, evacuated then filled with $\mathrm{H}_{2}+\mathrm{CO}_{2}$ $(90: 10, \mathrm{v} / \mathrm{v})$. The cultures were then kept in cold store for several months.

General media for, and cultivation of, non-wine leuconostocs. These strains were 
grown in yeast glucose citrate broth (YGCB) consisting of (w/v): Evans peptone, I. $0 \%$; Lemco, I. O \%; Yeastrel, $0.5 \%$; glucose, $\mathrm{I} \cdot 0 \%$; triammonium citrate, $0.5 \%$; sodium acetate, $0.2 \% ; \mathrm{MgSO}_{4} .7 \mathrm{H}_{2} \mathrm{O}, 0.02 \% ; \mathrm{MnSO}_{4} .4 \mathrm{H}_{2} \mathrm{O}, 0.005 \%$; and (v/v): Tween $80,0.1 \%$; $\mathrm{pH} 6.7$; autoclaved $121^{\circ}$ for $15 \mathrm{~min}$.

Table I. Source of cultures of Leuconostoc examined

\begin{tabular}{cll} 
NCDO no. & Designation when received & \multicolumn{1}{c}{ Donor } \\
I668 & Plince 3 & \\
I669 & St Caprais I05 & \\
I670 & Ducru Beaucaillon 6 & \\
I671 & Brane 33 & \\
I672 & Fourtet I & E. Peynaud, \\
I673 & Peyreau I & Station Agronomique \\
I674 & Baudry I & et Oenologique, \\
I675 & St Caprais I33 & Bordeaux, \\
I705 & Fourtet 2 & France \\
I706 & Grand Puy 3 & \\
1707 & Palmer 6 & \\
I708 & St Caprais 131 & \\
I709 & St Caprais I22 & \\
I694 & I2 A & \\
I695 & I6 A & F. Radler, \\
I696 & 45 B & C.S.I.R.O., \\
I821 & ML 25 & Merbein, Australia \\
I822 & ML 27 & R. E. Kunkee, \\
I823 & ML 34 & University of \\
\end{tabular}

Cysteine hydrochloride was added before inoculation with Leuconostoc cremoris (Betacoccus cremoris, Knudsen \& Sørensen, 1929) and cultures of strains of this species were incubated at $22^{\circ}$ for $48 \mathrm{hr}$. The same conditions of growth were used for a few group III strains (Garvie, 1960). All other strains were incubated at $30^{\circ}$ for $24 \mathrm{hr}$ (without cysteine hydrochloride).

The turbidity (extinction) of cultures was measured in ATB or YGCB with a Lumetron colorimeter model $400 \mathrm{~A}$ (Photovolt Corporation, N.Y.) and an orange $(580 \mathrm{~m} \mu$ ) filter.

Growth at $\mathrm{pH} 3.7$ was tested in citric + malic acid broth (CMB) which consisted of (w/v): Evans peptone, $\mathrm{I} \cdot 0 \%$; Yeastrel, $0.5 \%$; glucose, $\mathrm{I} \cdot 0 \%$; citric acid, $0.25 \%$; DL-malic acid, $0.25 \% ; \mathrm{KH}_{2} \mathrm{PO}_{4}, 0.25 \% ; \mathrm{MgSO}_{4} \cdot 7 \mathrm{H}_{2} \mathrm{O}, 0.02 \% ; \mathrm{MnSO}_{4} \cdot 4 \mathrm{H}_{2} \mathrm{O}, 0.005 \%$; and $(\mathrm{v} / \mathrm{v})$ : Tween $80,0.1 \%$; tomato juice, $5.0 \%$. The medium was divided and portions adjusted to $\mathrm{pH} 6 \cdot 7,4 \cdot 7$ or $3 \cdot 7$, tubed in $5 \mathrm{ml}$. quantities, and sterilized by autoclaving at $12 \mathrm{I}^{\circ}$ for $\mathrm{I} 5 \mathrm{~min}$. (The $\mathrm{pH}$ value of the media did not change on sterilization.) Cysteine hydrochloride was added for the strains of Leuconostoc oenos and $L$. cremoris and tubes were inoculated with one drop of a culture in ATB or YGCB. All cultures were seeded into $\mathrm{CMB}$ at $\mathrm{pH} 3 \cdot 7$. Control cultures of $L$. oenos were grown in $\mathrm{CMB}$ at $\mathrm{pH} 4 \cdot 7$ and for control cultures of other strains in $\mathrm{CMB}$ at $\mathrm{pH} 6.7$.

Growth in the presence of $10 \%(v / v)$ ethanol. CMB was prepared at double strength and adjusted to $\mathrm{pH}_{4.7}$ for Leuconostoc oenos, and $\mathrm{pH} 6.7$ for other species. The medium was tubed in $2.5 \mathrm{ml}$. quantities and water added to bring the volume to $4.5 \mathrm{ml}$. (0.25 ml. less for those strains to which cysteine hydrochloride was added). The medium was autoclaved at $121^{\circ}$ for $\mathrm{I} 5 \mathrm{~min}$., cooled and $0.5 \mathrm{ml}$. absolute ethanol 
then added. Tubes were inoculated with a drop of culture, closed with a sterile rubber bung and incubated for 4 days for $L$. oenos or I-2 days for other species.

Growth in litmus milk (LM) and yeast glucose litmus milk (YGLM). Cultures were incubated at $22^{\circ}$ for 7 days.

Growth temperatures. Growth was observed in ATB (with cysteine hydrochloride added) after incubation for 3 days at $37.5^{\circ}$ and 7 days at $10^{\circ}$.

Production of ammonia from arginine. Cultures were grown at $22^{\circ}$ for 7 days in the medium used by Garvie (1960) and in MRSB (de Man, Rogosa \& Sharpe, 1960) prepared without ammonium citrate but with $0.3 \%$ arginine hydrochloride. Nessler's solution was used to test for the production of ammonia.

Production of dextran from sucrose. One $\mathrm{ml}$. of a $50 \%(\mathrm{w} / \mathrm{v})$ solution of sucrose, sterilized by autoclaving at $\mathrm{I} 2 \mathrm{I}^{\circ}$ for $\mathrm{I} 5 \mathrm{~min}$., was added to $\mathrm{IO} \mathrm{ml}$. ATB agar and plates poured and streaked. Since the wine leuconostocs do not grow aerobically the plates were incubated as already described in an atmosphere of $\mathrm{H}_{2}+\mathrm{CO}_{2}$ for $\mathrm{I} 4$ days.

Utilization of citrate. One $\mathrm{ml}$. of a $10 \%(\mathrm{w} / \mathrm{v})$ solution of triammonium citrate was added to ro ml. ATB, cysteine added and the tubes inoculated. After 3 days' incubation at $22^{\circ}$ the residual citrate was assayed by using Streptococcus lactis var. diacetilactis NCDO 1007 (Garvie, 1967a).

Type of lactic acid formed. The cultures were incubated for 3 days in dilute tomato broth (Garvie, $1967 b$ ). The type of lactic acid formed was estimated by using a DPN method for $\mathrm{L}(+)$-lactate and a modification of the method of van den Hamer \& Elias (1958) for $\mathrm{D}(-)$-lactate (Garvie, $1967 \mathrm{~b}$ ).

'Carbohydrate' fermentation. The basal medium consisted of (w/v): Evans peptone, $\mathrm{I} .5 \%$; Yeastrel, $0.6 \%$; NaCl, $0.5 \%$; agar, $0.5 \%$; bromcresol green, $0.004 \%$; $\mathrm{pH} 5.2$. The medium was prepared in $5 \mathrm{ml}$. quantities in 6 in. $\times \frac{3}{8}$ in. test tubes and autoclaved at $\mathrm{I} 2 \mathrm{I}^{\circ}$ for $\mathrm{I} 5 \mathrm{~min}$. The tubes were placed in boiling water to melt the agar, cooled to $45^{\circ}$ and $0.5 \mathrm{ml}$. of $2 \%(\mathrm{w} / \mathrm{v})$ Seitz filtered 'Carbohydrate' added. The tubes were inoculated with $0.2 \mathrm{ml}$. of a 3-day culture, allowed to set and incubated for 2I days at $22^{\circ}$.

The production of gas from glucose. The method of Abd-el-Malek \& Gibson (1948) was used.

Catalase was detected by emulsifying the growth from agar in a drop of $\mathrm{H}_{2} \mathrm{O}_{2}$ (20 vol.) and observing gas formation.

\section{RESULTS}

All the nineteen strains of wine leuconstocs were Gram-positive, catalase negative, and formed pairs of chains of cocci. They formed gas from glucose, did not form ammonia from arginine and did not change litmus milk. They formed $\mathrm{D}(-)$-lactic acid. These properties are characteristic of bacteria which belong to the genus Leuconostoc.

\section{Growth conditions for wine leuconostoc}

YGCB did not support the growth of five of the wine leuconostoc strains (Garvie \& Mabbitt, 1967). All nineteen strains grew in ATB, but maximum turbidity was obtained only after several days of incubation. A comparison was made between the growth of the wine cocci and thirty-two other leuconostocs, in both YGCB and ATB. Both media were prepared at $\mathrm{pH}$ values of $6 \cdot 7,6 \cdot 0,5 \cdot 5$ and $4 \cdot 8$. (It was found, as with $\mathrm{CMB}$, that the $\mathrm{pH}$ values of YGCB and ATB did not change on sterilization.) 
The results are summarized in Table 2.

Of the non-wine leuconostocs (groups I-IV) only three strains (Leuconostoc paramesenteroides; Garvie, I967c) grew well in YGCB starting at $\mathrm{pH} 4 \cdot 8$, and of these only two grew in ATB starting at the same $\mathrm{pH}$ value. The other twenty-nine cultures did not grow in media at $\mathrm{pH} 4.8$ but they grew in both media starting at $\mathrm{pH} 6.7$, giving a higher extinction in YGCB than ATB. Maximum turbidity was reached in $24 \mathrm{hr}$ for most strains, but $48 \mathrm{hr}$ were required for $L$. cremoris and other strains which grow best at $22^{\circ}$. None of the strains which grew in ATB at initial pH 4.8 grew in

Table 2. Range of turbidity (extinction) readings obtained on cultures of Leuconostocs grown in yeast glucose citrate broth (YGCB) and acidic tomato broth (ATB)

\begin{tabular}{|c|c|c|c|c|c|}
\hline & & & Medi & $\mathrm{am}$ & \\
\hline & & & & AT & \\
\hline & & & Initial pF & value & \\
\hline & $\begin{array}{c}\text { strains } \\
\text { exa- }\end{array}$ & pH 6.7 & $\begin{array}{l}\mathrm{pH}_{4} \cdot 8 \\
\quad \text { Lumetro }\end{array}$ & $\begin{array}{l}\text { pH } 6.7 \\
\text { readings }\end{array}$ & $\mathrm{pH}_{4} \cdot 8$ \\
\hline L. cremoris & 6 & $3 \cdot I-I \cdot 6$ & $0.6-0.0$ & $2 \cdot 0-I \cdot I 5$ & 0.0 \\
\hline L. lactis & 3 & $3 \cdot 5-2 \cdot 2$ & $0.65-0.4$ & $2 \cdot 7-1 \cdot 4$ & $1 \cdot 1-0 \cdot 0$ \\
\hline I. L. paramesenteroides & 6 & $5 \cdot x-3 \cdot 2$ & $5 \cdot 1-0 \cdot 0$ & $5 \cdot 8-0.7$ & $3 \cdot 7-0.5$ \\
\hline$I$ dertranicum & 3 & $3 \cdot I-2 \cdot 7$ & $0.7-0.2$ & $2 \cdot 6-I \cdot 9$ & $0.5-0.25$ \\
\hline L. dextrantcum & 4 & $4 \cdot 0-2 \cdot I$ & $I \cdot 3-0.0$ & $3 \cdot 6-1 \cdot 7$ & $0.7-0.2$ \\
\hline I. L. mesenteroides & 10 & $4 \cdot 9-3 \cdot 6$ & $2.0-0.0$ & $3 \cdot 8-2 \cdot 5$ & $1 \cdot 8-0.7$ \\
\hline II a) & 5 & $1 \cdot 2-0 \cdot 3$ & $2 \cdot 4-0.8$ & $4 \cdot 8-3 \cdot 5$ & $3 \cdot 7-2 \cdot 6$ \\
\hline $\mathrm{II}$ b $\}^{L}$. oenos & 14 & $4 \cdot 0-2 \cdot 0$ & $4 \cdot 2-I \cdot 7$ & $5 \cdot 4-3 \cdot 0$ & $4 \cdot 7-2 \cdot 2$ \\
\hline
\end{tabular}

* Leuconostoc species named according to Garvie (1967c).

CMB at initial $\mathrm{pH} 4.2$ or 3.7 . On the other hand, the wine strains grew well in ATB (initial $\mathrm{pH} 4.8$ ) and of these 14 also grew in YGCB starting at both $\mathrm{pH} 6.7$ and 4.8 but not as well as in ATB. Growth was slow with all strains and incubation was therefore continued for 3 days. All strains grew in CMB at initial $\mathrm{pH} 3.7$ but growth was not as good as at $\mathrm{pH} 4.2$ or 4.7 . A few strains gave slight growth in CMB adjusted to $\mathrm{pH} 3 \cdot 2$. The ability to grow well in CMB (initial $\mathrm{pH} 4 \cdot 2$ ) is used to separate Leuconostoc oenos from other species of the genus, for these do not grow in this medium. The addition of cysteine to the medium had a greater effect on those strains of L.oenos which did not grow in YGCB than on those which grew in this medium. The growth of most strains was improved by the addition of cysteine; for five strains it was essential.

\section{Characteristics of the wine leuconostocs}

Table 3 gives the results obtained with the wine leuconostocs and compares them with the characteristics of other species (Garvie, 1960).

In the earlier work the fermentative properties of strains were examined in a medium adjusted to $\mathrm{pH} 6.7$ and with bromcresol purple (BCP) as indicator, but since the wine strains grew better in media adjusted to a more acid $\mathrm{pH}$ value they were examined in a different medium adjusted to $\mathrm{pH} 5.2$ and with bromcresol green as indicator. However, I2 strains (two of each species) previously examined in BCP medium were tested in the low $\mathrm{pH}$ medium; the fermentation pattern was found to be 
unaffected by the change of medium. The substances fermented are shown in Table 3 . Although there was no tomato juice in the medium results were obtained with all strains of Leuconostoc oenos by using the techniques described. On a few occasions a smaller inoculum or washed organisms were tried but acid was not formed from any substrate.

Table 3. The characters of the species of the genus Leuconostoc

Figures in parentheses are the numbers of strains examined in that particular test. Where no figures in parentheses are given all strains were examined. Other figures give the number of strains giving a positive reaction.

\begin{tabular}{|c|c|c|c|c|c|c|c|}
\hline & \multirow{2}{*}{$\begin{array}{l}L . \\
\text { cremoris } \\
\text { Group I }\end{array}$} & \multirow[b]{2}{*}{$\begin{array}{l}\text { L. lactis } \\
\text { Group II }\end{array}$} & \multirow[b]{2}{*}{$\begin{array}{l}\text { L. oenos } \\
\text { Group VII }\end{array}$} & \multirow{2}{*}{$\begin{array}{c}\text { L. para- } \\
\text { mesen- } \\
\text { teroides } \\
\text { Group III }\end{array}$} & \multicolumn{2}{|c|}{ L. dextranicum } & \multirow{2}{*}{$\begin{array}{l}\text { L. mesen- } \\
\text { teroides } \\
\text { Group VI }\end{array}$} \\
\hline & & & & & Group IV & Group V & \\
\hline No. of strains examined ... & IO & 9 & 19 & 17 & 5 & 16 & $3 I$ \\
\hline Growth in YGCB* & $+(6)$ & $+(3)$ & 14 & $+(6)$ & $+(3)$ & $+(4)$ & $+(10)$ \\
\hline $\begin{array}{l}\text { Growth in ATB* better than } \\
\text { YGCB }\end{array}$ & $-(6)$ & $-(3)$ & + & $-(6)$ & $-(3)$ & $-(4)$ & $-(10)$ \\
\hline $\begin{array}{l}\text { Growth in } 10 \%(v / v) \\
\text { ethanol in } \mathrm{CMB}^{*}\end{array}$ & $-(2)$ & $-(2)$ & + & $-(2)$ & $-(2)$ & $-(2)$ & $-(2)$ \\
\hline Growth at $\mathrm{pH} 4.8$ in $\mathrm{CMB}$ & $-(6)$ & $-(3)$ & + & $2(6)$ & $-(2)$ & $-(4)$ & Slight (Io) \\
\hline Growth at $\mathrm{pH}_{3.7}$ in $\mathrm{CMB}$ & $-(2)$ & $-(2)$ & + & $-(2) \dagger$ & $-(2)$ & $-(2)$ & $-(2)$ \\
\hline Growth at $37.5^{\circ}$ & - & + & 15 & 14 & 4 & + & 28 \\
\hline YGLM* reaction acid & + & + & 10 & 17 & + & + & + \\
\hline clot & 4 & 2 & - & IO & + & 15 & 27 \\
\hline reduction & $\mathbf{I}$ & 2 (slight) & 2 & 2 & + & 12 & 26 \\
\hline gas & $\mathbf{I}$ & - & - & 2 & $\mathbf{I}$ & 7 & I4 \\
\hline Dextran synthesis & - & - & - & - & + & + & + \\
\hline Dissimilation of citrate & $+(6)$ & I (5) & I 8 & I (8) & & (I3) & $2($ II) \\
\hline Acid from arabinose & - & I & 9 & 16 & - & - & + \\
\hline xylose & - & - & 3 & 5 & - & + & 24 \\
\hline fructose & - & 7 & + & 16 & + & 14 & 30 \\
\hline glucose & + & + & + & + & + & + & + \\
\hline galactose & + & + & 4 & + & 3 & I3 & 29 \\
\hline mannose & - & 8 & I I & + & + & 15 & 30 \\
\hline cellobiose & - & - & I3 & 7 & - & 3 & 19 \\
\hline lactose & + & + & - & 5 & 2 & 10 & 16 \\
\hline maltose & - & + & - & 16 & 3 & + & 29 \\
\hline sucrose & - & 8 & - & 15 & 4 & + & + \\
\hline trehalose & - & I & + & + & + & + & + \\
\hline melibiose & - & 8 & 14 & + & - & 15 & 25 \\
\hline raffinose & - & 3 & - & 7 & - & 9 & I 6 \\
\hline dextrin & - & - & - & 6 & - & - & - \\
\hline aesculin & - & - & + & 7 & - & 8 & 29 \\
\hline salicin & - & - & I4 & - & - & 3 & 24 \\
\hline mannitol & - & - & - & 7 & - & 3 & II \\
\hline
\end{tabular}

$\dagger$ The two strains which grow at $\mathrm{pH} 4 \cdot 8$.

- YGCB = yeast glucose citrate broth; $\mathrm{ATB}=$ acidic tomato broth; $\mathrm{CMB}=$ citric-malic acid broth; YGLM $=$ yeast glucose litmus milk.

\section{DISCUSSION}

It is suggested that the wine leuconostocs should be separated from other species of the same genus because the wine strains grow in media with a low initial $\mathrm{pH}$ value (i.e. $3 \cdot 7$ ) and grow well at $\mathrm{pH} 4 \cdot 2$, while other leuconostocs will not grow in media with an initial $\mathrm{pH}$ value of $4 \cdot 2$ or less. Acid tolerance is not the only property which 
separates the wine strains from all the other species. Failure to ferment sucrose and maltose excludes them from all species except Leuconostoc cremoris while failure to ferment lactose and (usually) galactose together with the ability to form acid from fructose, aesculin and (usually) salicin and melibiose excludes them from $L$. cremoris. For reasons given elsewhere (Garvie, $1967 c$ ) L. dextranicum and L. mesenteroides are considered to include only strains which form dextran from sucrose. The non-slime forming strains previously included in $L$. mesenteroides are placed in a new species $L$. paramesenteroides. The wine cultures do not form slime, and are therefore excluded from $L$. dextranicum and $L$. mesenteroides. $L$. paramesenteroides is most likely to be confused with the wine strains but acid production from maltose, sucrose, salicin and aesculin should put the majority of strains in the correct species.

Table 4. The separation of six proposed species of Leuconostoc

\begin{tabular}{|c|c|c|c|c|c|c|}
\hline & $\begin{array}{l}\text { L. mesen- } \\
\text { teroides }\end{array}$ & $\begin{array}{l}\text { L. dextra- } \\
\text { nicum }\end{array}$ & $\begin{array}{l}\text { L.para- } \\
\text { mesen- } \\
\text { teroides }\end{array}$ & L. lactis & $\begin{array}{l}\text { L. } \\
\text { cremoris }\end{array}$ & L. oenos \\
\hline Production of slime from sucrose & + & + & - & - & - & - \\
\hline $\begin{array}{l}\text { Acid formed from arabinose } \\
\qquad \begin{array}{l}\text { lactose } \\
\text { maltose } \\
\text { sucrose } \\
\text { trehalose }\end{array}\end{array}$ & $\begin{array}{l}+ \\
\pm \text { (slow) } \\
\mathrm{u}+ \\
+ \\
+\end{array}$ & $\begin{array}{l}- \\
\pm(\text { slow) } \\
\mathrm{u}+ \\
\mathrm{u}+ \\
+\end{array}$ & $\begin{array}{c}\mathrm{u}+ \\
\pm(\text { slow) } \\
\mathrm{u}+ \\
\mathrm{u}+ \\
+\end{array}$ & $\begin{array}{r}\mathbf{u}- \\
+ \\
+ \\
\mathbf{u +} \\
\mathbf{u}-\end{array}$ & $\begin{array}{l}- \\
+ \\
- \\
- \\
-\end{array}$ & $\begin{array}{l} \pm \\
- \\
- \\
- \\
+\end{array}$ \\
\hline $\begin{array}{l}\text { Hydrolysis of aesculin } \\
\text { salicin }\end{array}$ & $\begin{array}{l}\mathbf{u}+ \\
\mathbf{u}+\end{array}$ & $\begin{array}{l}\mathrm{u}- \\
\mathrm{u}-\end{array}$ & \pm & $\begin{array}{l}- \\
-\end{array}$ & $\begin{array}{l}- \\
-\end{array}$ & $\begin{array}{r}+ \\
\mathrm{u}+\end{array}$ \\
\hline 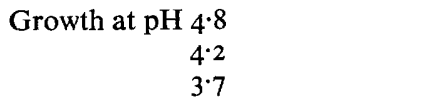 & $\begin{array}{c}\text { - or slight } \\
- \\
-\end{array}$ & $\begin{array}{c}\text { - or slight } \\
- \\
-\end{array}$ & $\begin{array}{l} \pm \\
- \\
-\end{array}$ & $\begin{array}{l}- \\
- \\
-\end{array}$ & $\begin{array}{l}- \\
- \\
-\end{array}$ & $\begin{array}{l}+ \\
+ \\
+\end{array}$ \\
\hline
\end{tabular}

When strains of Leuconostocs oenos were first cultured in this laboratory growth was poor. When strains of other Leuconostoc species had been difficult to grow the addition of cysteine hydrochloride to the medium greatly improved growth. This was therefore tried with $L$. oenos and was successful. The Leuconostoc strains encouraged by cysteine had also been found to grow well on agar media when incubated in anaerobic jars evacuated and filled with a mixture of hydrogen and carbon dioxide, while growth of these strains on nutrient agar when incubated aerobically is unreliable. Similarly, L. oenos does not grow aerobically on agar media. The addition of cysteine to broth media and incubation of plates in an atmosphere of hydrogen + carbon dioxide has not been found to inhibit the growth of any leuconostocs and is useful for growing all strains of $L$. cremoris, strains received from Dr Whittenbury as representative of his group I (Whittenbury, 1966) and also for a few other strains of $L$. paramesenteroides and a few of $L$. dextranicum.

Fornachon (1964) and Malan, Ozino \& Gandini (I965) reported sucrose fermentation by strains of leuconostocs they isolated from wine. Although in both these papers the cultures were regarded as belonging either to Leuconostoc mesenteroides or L. dextranicum the $\mathrm{pH}$ value of the media used makes this classification appear unlikely and the cultures described appear to be $L$. oenos. It is possible that some strains or under some conditions acidophilic leuconostocs ferment sucrose (see below). As 
might be expected wine leuconostocs are more tolerant to ethanol than are other leuconostocs. It is proposed to call the wine strains L. oenos. A suggested differential key is given in Table 4: other differences between the species are shown in Table 3.

Difficulties in naming leuconostocs found in wine have been reported previously. Bidan (1956) was unable to give a species name to one of his strains, the other he called Leuconostoc gracile. This name was chosen because Pedersen (Bergey's Manual, I948) had found that one strain of 'Bacterium gracile' (Muller-Thurgau \& Osterwalder, I9I3, I9I8) which he received from Dr A. Osterwalder was probably a leuconostoc. Neither this strain nor any of the originals are now available and it is not possible to be sure that the original description of ' $B$. gracile' referred to a leuconostoc. Since Bidan's culture fermented lactose and raffinose it is doubtful whether it was the same as the present wine strains. Radler (1958) concluded his cultures were like, but not identical with, L. citrovorum, and Pilone \& Kunkee (1965) use the name L. citrovorum for ML 34 (NCDO I823). Radler's strains and strain ML 34 are included in the present work and are typical of $L$. oenos. Fornachon (1964) described acidophilic cocci found in Australian wine and concluded that they were non-dextran forming varieties of $L$. mesenteroides. Two strains received from Dr J. C. M. Fornachon while this paper was in preparation were found to be L. oenos. Similarly, of six strains received from Professor C. E. Malan as L. mesenteroides, L. dextranicum and L. citrovorum, five are $L$. oenos and one has not been satisfactorily identified. Using the methods given none of these eight strains formed acid from sucrose.

The gas-forming cocci isolated from wine and gas-forming cocci isolated from other sources have not always been seen to be different, partly perhaps because leuconostocs have been confused amongst themselves and also with organisms of other genera. Leuconostoc cremoris seems to be found only in the field of dairy bacteriology, but other species are more widely distributed. At this time the true taxonomic significance of the ability to tolerate and grow at acid $\mathrm{pH}$ values cannot be assessed, but since this property is linked with differences which have classically been used as a means of separation among the lactic-acid bacteria, acid tolerance is an additional argument for defining a new species.

Leuconostoc oenos is not a homogenous group and some strains are considerably easier to grow than others. It is difficult to select a type strain, however, NCDO I674 is proposed.

\section{REFERENCES}

AbD-el-MaleK, Y. \& Gibson, T. (I948). Studies in the bacteriology of milk. I. The streptococci of milk. J. Dairy Res. 15, 233.

Bergey's Manual of Determinative Bacteriology (1948). 6th edition. London: Baillière Tindall and Cox.

Bidan, P. (1956). Sur quelques bactéries isolées de vins en fermentation malolactique. Ann. Tech. agric. 5, 597.

ForNACHON, J. C. M. (I964). A Leuconostoc causing malo-lactic fermentation in Australian wines. Am. J. Enol. Vitic. 15, 597.

GARVIE, E. I. (1960). The genus Leuconostoc and its nomenclature. J. Dairy Res. 27, 283.

GARVIE, E. I. (1967a). Some factors affecting the production of acetoin by Streptococcus lactis var. diacetilactis $\mathrm{NCDO} 1007$, and a method of detecting citrate dissimilation by lactic acid bacteria J. Dairy Res. 34, 39.

GARVIE, E. I. $(1967 b)$. The production of $L(+)$ and $\mathbf{D}(-)$ lactic acid in cultures of some lactic acid bacteria with a special study of Lactobacillus acidophilus NCDO 2. J. Dairy Res. 34, 31 .

GARVIE, E. I. (1967c). The growth factor and amino acid requirements of species of the genus Leuconostoc, including Leuconostoc paramesenteroides (sp. nov.) and L. oenos. J. gen Microbiol. $48,439$. 
GARVIE, E. I. \& MABBrTt, L. A. (1967). Stimulation of the growth of Leuconostoc oenos by tomato juice. Arch. Mikrobiol. 55, 398.

vaN DEN HAMER, C. J. A. \& Elias, R. W. (1958). A method for the determining of D(-) lactic acid. Biochim. biophys. Acta 29, 556.

Ingraham, J. L., Vaughn, R. H. \& Cooke, G. M. (I960). Studies on the malo-lactic organisms isolated from Californian wine. Am. J. Enol. Vitic. II, I.

Knudsen, S. \& Sørensen, A. (1929). Bidrag til syrevaekkernes Bakteriologi. Den Kgl. Veterinaerog Landbohojskole Aarsskrift. 64.

Malan, C. E., Ozino, O. I. \& GANDINI, A. (1965). Gli schizomiceti della fermentazione malo-lattica di alcuni vini del Piemonte ed: Blastomiceti, predominanti nel corso della loro attività. Arti. Acad. ital tito Vino Siena $\mathbf{1 7}, 235$.

de Man, J. C., Rogosa, M. \& Sharpe, M. E. (1960). A medium for the cultivation of Lactobacilli. J. app. Bact. 23, 130 .

Müller-Thurgau, H. \& Osterwalder, A. (1913). Die Bakterien in Wein und Obstwein und die dadurch verursachten Veränderungen. Zentbl. Bakt. (Abt. 2) 36, I29.

Müller-Thurgau, H. \& Osterwalder, A. (I9I8). Weitere Beiträge zur Kenntnis der Mannitbakterien in Wein. Zentbl. Bakt. (Abt. 2), 48, I.

Peynaud, E. \& DomercQ, S. (196I). Études sur les bactéries lactiques des vins. Ann. Tech. agric. 1o, 43.

Pilone, G. J. \& KunKeE, R. E. (1965). Sensory characterisation of wines fermented with several malolactic strains of bacteria. Am. J. Enol. Vitic. 16, 224.

RADLER, F. (1958). Untersuchung des biologischen Säureabbaus im Wein Isolierung und Charakterisierung von Apfelsaure-abbauenden Bakterien. Arch. Mikrobiol. 30, 64.

Whittenbury, R. (1966). A study of the genus Leuconostoc. Arch. Mikrobiol. 53, 317. 